\title{
Transmural dispersion of repolarization and atrial electromechanical coupling: complementary indices for quantifying cardiac electrical heterogeneity in patients with conversion disorder
}

\author{
This article was published in the following Dove Press journal: \\ Therapeutics and Clinical Risk Management \\ 20 July 2015 \\ Number of times this article has been viewed
}

\author{
Alptug Tokatli' \\ Omer Yiginer ${ }^{2}$ \\ Gokhan Degirmencioglu ${ }^{2}$ \\ Fethi Kilicaslan ${ }^{3}$ \\ Mehmet Uzun ${ }^{2}$ \\ 'Department of Cardiology, \\ Golcuk Military Hospital, Kocaeli, \\ ${ }^{2}$ Department of Cardiology, GATA \\ Haydarpasa Hospital, ${ }^{3}$ Department \\ of Cardiology, Medipol University, \\ Istanbul, Turkey
}

\section{Dear editor}

We read with great interest the article entitled "P-wave and QT dispersion in patients with conversion disorder" by Izci et al ${ }^{1}$ in Therapeutics and Clinical Risk Management. In this well designed research, Izci et al studied QT dispersion (QTd) and P-wave dispersion (Pd) in patients with conversion disorder (CD). In conclusion, they reported that corrected QT (QTc) and QTd values were significantly altered in patients with CD when compared to healthy controls, but that there was no significant difference in terms of Pd.

It has been postulated that the relationship between somatoform disorders and CD is related to altered autonomic functions. ${ }^{2}$ These changes may affect the refractory period and conduction velocity of the heart. In line with these assumptions, heterogeneity in the duration of the ventricular repolarization phase leading to arrhythmias may also be seen in patients with CD. As in this study, QTd is the most frequently used parameter to detect ventricular inhomogeneity. However, reproducibility of QT interval measurements is low in both manual and automatic measurements and interobserver and intraobserver variability of QTd is very high. ${ }^{3,4}$ Quantifying the inhomogeneity of the myocardium, transmural dispersion of repolarization (TDR) has also been used since the beginning of the 2000s in addition to QTd. ${ }^{5}$ There are three types of myocyte, ie, endocardial, epicardial, and midmyocardial M cells, each having different electrophysiological properties in the ventricular myocardium. Midmyocardial $\mathrm{M}$ cells have typically the longest repolarization phase. The repolarization phase of the midmyocardial M cells continues until the end of the T-wave. However, the repolarization phase of the epicardial cells ends at the peak of the T-wave. The time between the peak and end of the T-wave is known as the Tp-e interval, and is an index of the TDR. ${ }^{5}$ In addition, the Tp-e/QT ratio has also been used as an electrical dispersion index for the myocardium, showing arrhythmic risk. The role of the TDR in evaluation of arrhythmic risk has been demonstrated in coronary artery disease and in the Brugada, short QT, and long QT syndromes. Previously, we showed that the Tp-e interval was increased in patients with obstructive sleep apnea. ${ }^{6}$

On the other hand, the basic electrophysiological characteristics of the atrium that predispose to atrial arrhythmias are prolongation of intra-atrial and interatrial conduction times and heterogeneous propagation of sinus impulses. Pd is an accepted marker of atrial depolarization heterogeneity and the altered propagation of sinus
Correspondence: Alptug Tokatli Golcuk Asker Hastanesi, Kardiyoloji Servisi, 12 Donanma Street, Golcuk, Kocaeli 41910 , Turkey

Tel +902624260271

Fax +90262414 IIII

Email alptugtokatli@gmail.com 
impulses found to be associated with increased risk of atrial fibrillation. Although prolonged Pd values were found to be correlated with atrial fibrillation, it is controversial whether $\mathrm{Pd}$ is related to heterogeneity of atrial conduction or to other factors. Furthermore, reproducibility of P-wave measurements is low in both manual and automatic measurements and interobserver and intraobserver variability is very high. Atrial electromechanical coupling (AEC) can be assessed by electrocardiography-integrated tissue Doppler imaging and provides a means to determine the atrial mechanical and electrical event. Analysis of AEC by tissue Doppler imaging allows precise analysis of AEC between different regions. Moreover, measurement of AEC may suggest an inhomogeneous propagation of sinus impulses in different cardiac sites. Autonomic dysregulation and altered sympathovagal balance, as in somatoform disorders, may account for heterogeneity in atrial conduction properties. Measurement of AEC has been done in patients with psoriasis, ankylosing spondylitis, hyperthyroidism, end-stage renal disease, and hypertension. ${ }^{7-9}$ Regarding these observations, autonomic imbalance may cause atrial depolarization and sinus impulse propagation abnormalities leading to altered AEC.

Our opinion is that, if AEC intervals had been measured in this study, they may have been found to be altered in patients with CD. Further, regarding the forementioned observations, if Izci et al had measured the Tp-e interval and Tp-e/QT ratio in their study, they might have found an increased TDR in their patients with $\mathrm{CD}$. Considering all the data about $\mathrm{Pd}$,
AEC, QTd, and TDR, their study might have revealed the effects of CD on electrical heterogeneity of the myocardium more completely in many respects.

\section{Disclosure}

The authors report no conflicts of interest in this communication.

\section{References}

1. Izci F, Hocagil H, Izci S, Izci V, Koc MI, Acar RD. P-wave and QT dispersion in patients with conversion disorder. Ther Clin Risk Manag. 2015; 11:475-480.

2. Laederach-Hofmann K, Röddel H, Mussgay L. Pathological baroreceptor sensitivity in patients suffering from somatization disorders: do they correlate with symptoms? Biol Psychol. 2008;79:243-249.

3. Statters DJ, Malik M, Ward DE, Camm AJ. QT dispersion: problems of methodology and clinical significance. J Cardiovasc Electrophysiol. 1994;5:672-685.

4. Kasamaki Y, Ozawa Y, Ohta M, et al. Automated versus manual measurement of the QT interval and corrected QT interval. Ann Noninvasive Electrocardiol. 2011;16:156-164.

5. Antzelevitch C. Tpeak-Tend interval as an index of transmural dispersion of repolarization. Eur J Clin Invest. 2001;31:555-557.

6. Kilicaslan F, Tokatli A, Ozdag F, et al. Tp-e interval, Tp-e/QT ratio, and $\mathrm{Tp}$-e/QTc ratio are prolonged in patients with moderate and severe obstructive sleep apnea. Pacing Clin Electrophysiol. 2012; 35:966-972.

7. Acar G, Sayarlioglu M, Akcay A, et al. Assessment of atrial electromechanical coupling characteristics in patients with ankylosing spondylitis. Echocardiography. 2009;26:549-557.

8. Yildiz A, Ucmak D, Oylumlu M, et al. Assessment of atrial electromechanical delay and P-wave dispersion in patients with psoriasis. Echocardiography. 2014;31:1071-1076.

9. Ayhan S, Ozturk S, Dikbas O, et al. Detection of subclinical atrial dysfunction by two-dimensional echocardiography in patients with overt hyperthyroidism. Arch Cardiovasc Dis. 2012;105:631-638. 


\section{Authors' reply}

Filiz '̇zci'

Hilal Hocagi ${ }^{2}$

Servet İzci ${ }^{3}$

Merve İris Koç ${ }^{4}$

Vedat İzci ${ }^{5}$

Rezzan Deniz Acar ${ }^{3}$

'Department of Psychiatry, Istanbul Bilim University, School of Medicine, Istanbul, ${ }^{2}$ Department of Emergency, Faculty of Medicine Hospital, Zonguldak Bulent Ecevit University, Zonguldak, ${ }^{3}$ Department of Cardiology, Kartal Kosuyolu High Specialization Training and Research Hospital, ${ }^{4}$ Department of Psychiatry, Erenköy Training and Research Hospital for Psychiatry, ${ }^{5}$ Department of Emergency, Kartal Training and Research Hospital, Istanbul, Turkey

Correspondence: Filiz İzci

İstanbul Bilim Üniversitesi, Tıp Fakültesi, Psikiyatri ABD, Abide-i

Hürriyet Cad I64. Șișli, İstanbul, Turkey

Tel +9021 22244966

Fax +90 2I 229| I245

Email filizizci@yahoo.com

\section{Dear editor}

We would like to thank Tokatli et al for their interest in our recent article in Therapeutics and Clinical Risk Management. ${ }^{1}$ We are very glad to be given the opportunity to answer their letter.

QTd and Pd are considered to be indicators of cardiac arrhythmias and have been investigated in many psychiatric disorders. In the literature, there are many studies examining the relationship between anxiety disorders and P-wave dispersion $(\mathrm{Pd}),{ }^{2}$ which is considered to be an indirect indicator of atrial fibrillation, and QT dispersion (QTd), ${ }^{3}$ which is considered to be an indirect indicator of ventricular arrhythmia. ${ }^{46}$ As in anxiety disorders, heart rhythm disturbances have been observed in patients with somatoform disorders, and a relationship between heart rate and psychiatric conditions is thought to exist. ${ }^{7,8}$

Pd is considered to be a sensitive and specific indicator of atrial fibrillation in various clinical conditions. ${ }^{9}$ Changes in cardiac atrial conduction are found to be associated with systemic autonomic symptoms observed during autonomic anxiety periods. In a study of healthy controls and 40 patients with panic disorder who experienced intense somatic symptoms, Pd was found to be prolonged in patients with panic disorder. ${ }^{10}$ In another study examining the relationship between the presence of arrhythmia in anxiety disorders and Pd, state anxiety was found to influence Pd more than trait anxiety. ${ }^{11}$ A study of 30 patients with hypochondriasis (a type of somatoform disorder) and 30 healthy controls revealed that Pd durations, which are considered to be associated with anxiety, were significantly higher in the patient group. ${ }^{12}$ QTd was found to be significantly higher in patients with anxiety disorders, such as panic disorder and social phobia, than in controls, and this finding was thought to be associated with prolonged anxiety. ${ }^{5,6}$ Some studies have proposed that measured anxiety levels could be an indicator of prolonged QTd. ${ }^{13}$ QTd was found to be higher in patients with higher levels of anxiety. ${ }^{14}$ Also, in our study of patients with conversion disorder, which is a type of somatoform disorder, QTd was prolonged in the patient group and we mentioned that this group of patients might be at risk of ventricular arrhythmia. ${ }^{1}$

Recently, atrial electromechanical coupling (AEC) and transmural dispersion of repolarization (TDR) have been used to determine the risk of cardiac arrhythmia as well as Pd and QTd. ${ }^{15,16}$ However, as far as we know, no study has investigated the risk of cardiac arrhythmia using these parameters in psychiatric disorders such as conversion disorder. According to our study findings, there was no significant difference in terms of Pd between the patient and control groups; however, reviewing possible changes in atrial conduction using AEC may be useful. As Tokatli et al have mentioned, investigating the risk of cardiac arrhythmia using AEC and TDR in patients who have conversion disorder and significant somatization and anxiety symptoms and confirming these findings with further studies may lead to important contributions to the literature.

\section{Disclosure}

The authors report no conflicts of interest in this communication.

\section{References}

1. Izci F, Hocagil H, Izci S, Izci V, Koc MI, Acar RD. P-wave and QT dispersion in patients with conversion disorder. Ther Clin Risk Manag. 2015;11:475-480.

2. Aytemir K, Özer N, Atalar E, et al. Dispersion on 12 lead electrocardiography in patients with paroxysmal atrial fibrillation. Pacing Clin Electrophysiol. 2000;23:1109-1112.

3. Perkiömäki JS, Koistinen MJ, Yli-Mäyry S, Huikuri HV. Dispersion of QT interval in patients with and without susceptibility to ventricular tachyarrhythmias after previous myocardial infarction. J Am Coll Cardiol. 1995;26:174-179.

4. Unsal C, Kaplan OK, Saygın MK, Uzunlar B, Uyarel H, Çalışkan M. [P wave and QT dispersion in patients with generalized anxiety disorder]. Koşuyolu Kalp Dergisi. 2013;16:214-219. Turkish.

5. Nahshoni E, Gur S, Marom S, Levin JB, Weizman A, Hermesh H. QT dispersion in patients with social phobia. J Affect Disord. 2004;78: 21-26.

6. Atmaca M, Yavuzkir M, İzci F, Gurok MG, Adiyaman S. QT wave dispersion in patients with panic disorder. Neurosci Bull. 2012;28: 247-252.

7. Stampfer HG. The relationship between psychiatric illness and the circadian pattern of heart rate. Aust N Z J Psychiatry. 1998;32:187-198. 
8. Barsky AJ, Cleary PD, Coeytaux RR, Ruskin JN. Psychiatric disorders in medical outpatients complaining of palpitations. J Gen Intern Med. 1994;9:306-313.

9. Dilaveris PE, Gialafos EJ. P wave dispersion: a novel predictor of paroxysmal AF. Ann Noninvasive Electrocardiol. 2001;6:159-165.

10. Yavuzkir M, Atmaca M, Dagli N, et al. $\mathrm{P}$ wave dispersion in panic disorder. Psychosom Med. 2007;69:344-347.

11. Uyarel H, Kaşıkçıglu H, Dayı SU, et al. Anxiety and P wave dispersion in a healthy young population. Cardiology. 2005;104: $162-168$.

12. Atmaca M, Korkmaz H, Korkmaz S. P wave dispersion in patients with hypochondriasis. Neurosci Lett. 2010;485:148-150.
13. Uyarel H, Okmen E, Cobanoğlu N, Karabulut A, Cam N. Effects of anxiety on QT dispersion in healthy young men. Acta Cardiol. 2006; 61:83-87.

14. Kelmanson IA. High anxiety in clinically healthy patients and increased QT dispersion: a meta-analysis. Eur J Prev Cardiol. 2014; 21:1568-1574.

15. Watanabe N, Kobayashi Y, Tanno K, et al. Transmural dispersion of repolarization and ventricular tachyarrhythmias. J Electrocardiol. 2004;37:191-200.

16. Yildiz A, Ucmak D, Oylumlu M, et al. Assessment of atrial electromechanical delay and P-wave dispersion in patients with psoriasis. Echocardiography. 2014;31:1071-1076.

Dove Medical Press encourages responsible, free and frank academic debate. The content of the Therapeutics and Clinical Risk Management 'letters to the editor' section does not necessarily represent the views of Dove Medical Press, its officers, agents, employees, related entities or the Therapeutics and Clinical Risk Management editors. While all reasonable steps have been taken to confirm the content of each letter, Dove Medical Press accepts no liability in respect of the content of any letter, nor is it responsible for the content and accuracy of any letter to the editor.

\section{Publish your work in this journal}

Therapeutics and Clinical Risk Management is an international, peerreviewed journal of clinical therapeutics and risk management, focusing on concise rapid reporting of clinical studies in all therapeutic areas outcomes, safety, and programs for the effective, safe, and sustained use of medicines. This journal is indexed on PubMed Central, CAS,
EMBase, Scopus and the Elsevier Bibliographic databases. The manuscript management system is completely online and includes a very quick and fair peer-review system, which is all easy to use. Visit http://www.dovepress.com/testimonials.php to read real quotes from published authors. 